for the 15 to 18 year old girls who were dieting, who averaged $6.9 \mathrm{mg}$ a day, or $58 \%$ of the recommended daily allowance, throughout the period.

\section{Discussion}

In deficiency absorption increases, and in women with these low intakes it may be greater than the $6-7 \%$ estimated for the nation as a whole ${ }^{4}$; absorption might, however, need to be as high as $20-30 \%$ for several women in this study to meet the recommended daily allowance.

The energy as well as the iron intakes of these women were lower than the $8.0 \mathrm{MJ}(1911 \mathrm{kcal})$ and $10.1 \mathrm{mg}$ recorded by the Department of Health and Social Security (DHSS) for 14 to 15 year old schoolgirls in 1970 and $1971 .^{5}$ The iron intakes in the present study averaged $1.15 \mathrm{mg} / \mathrm{MJ}$ compared with $1.27 \mathrm{mg} / \mathrm{MJ}$ in the DHSS study and a recommendation equivalent to 1.34 $\mathrm{mg} / \mathrm{MJ} .^{3}$ Thus the low iron intakes resulted from diets of reduced iron concentration as well as from energy restriction.
Further research is needed to establish whether the haematological state of this population may be compromised or whether the current recommended daily allowances for iron are unnecessarily high. The results have been referred to the DHSS for consideration.

\section{References}

1 Ministry of Agriculture, Fisheries and Food. Household food consumption and expenditure: 1982. London: HMSO, 1984 .

2 Herçberg S, Soustre Y, Galán P, Berthier AM, Suquet JP, Dupin $H$ Apports alimentaires en fer dans une population de femmes françaises en âge de procréer. $1984 ; 28: 77-84$.

3 Department of Health and Social Security. Recommended daily amounts of food energy and nutrients for groups of people in the United Kingdom. London: $\mathrm{HMSO}$ energy and nutrients for groups of people
1979 . (Special report series No 15 .)

4 Bull NL, Buss DH. Haem and non-haem iron in British household diets. fournal of Human Nutrition $1980 ; \mathbf{3 4}: 141-5$

5 Darke SJ, Disselduff MM, Try GP. Frequency distribution of mean daily intakes of food energy and selected nutrients estimated during nutrition surveys of different groups of people in Great Britain between 1968 and 1971. Br $\mathcal{F}$ Nutr $1980 ; 44: 243-52$.

(Accepted 8 January 1985)

\title{
Hepatic sequestration in sickle cell anaemia
}

\author{
C S R HATTON C BUNCH, D J WEATHERALL
}

\begin{abstract}
Several episodes of acute hepatic enlargement associated with a dramatic fall in haemoglobin concentration were observed in two patients with sickle cell anaemia. No appreciable disturbances of liver function or signs of cardiac failure were evident. The most likely mechanism was sequestration of sickled erythrocytes in the liver. This complication, which may have a basis similar to that of splenic sequestration and the sickle lung syndrome, may be easily overlooked unless the size of the liver is regularly monitored in patients with sickle cell crisis.
\end{abstract}

\section{Introduction}

Patients with sickle cell anaemia may have periodic exacerbations of their illness, often referred to as sickling crises. Usually, these take the form of bone pain without an appreciable fall in the haemoglobin concentration. Less commonly, crises are characterised by dramatic and life threatening anaemia. This may result from transient marrow aplasia due to an intercurrent viral infection ${ }^{1}$ or massive sequestration of sickled erythrocytes in the spleen ${ }^{2}$ or pulmonary vasculature. ${ }^{3}$ Splenic sequestration occurs only in infants and young children.

Although there have been occasional reports of transient hepatic enlargement in patients with sickle cell disease, ${ }^{4-6}$ this complication has not received much attention in recent years. We describe three episodes of acute hepatic enlargement associated with a rapidly falling haemoglobin concentration in two patients with sickle cell anaemia.

\footnotetext{
Nuffield Department of Clinical Medicine, University of Oxford, John Radcliffe Hospital, Headington, Oxford OX3 9DU

C S R HATTON, MRCP, research fellow

C BUNCH, FRCP, clinical reader

D J WEATHERALL, FRCP, FRS, professor of medicine

Correspondence and requests for reprints to: Dr C S R Hatton.
}

\section{Case reports}

CASE 1

A 21 year old Nigerian woman with homozygous sickle cell anaemia was admitted with generalised bone pain; similar episodes had occurred from the age of 10 years. She did not have a fever but was slightly jaundiced, and her liver was just palpable below the right costal margin. Initial investigations showed haemoglobin concentration 8.1 $\mathrm{g} / \mathrm{dl}$, white cell count $20.6 \times 10^{9} / 1$, pletelet count $531 \times 10^{9} / \mathrm{l}$, reticulocyte count $8 \cdot 1^{\circ}$, , bilirubin concentration $34 \mu \mathrm{mol} / 1(2.0 \mathrm{mg} / 100 \mathrm{ml})$, aspartate transaminase activity $48 \mathrm{IU} / \mathrm{l}$, and alkaline phosphatase activity $255 \mathrm{IU} / \mathrm{l}$. A radiograph of the chest showed cardiac enlargement but no other abnormalities. She was treated with analgesics and intravenous fluids. The following day she was feverish, but the haematological findings were essentially the same. On the third morning her liver was enlarged $8 \mathrm{~cm}$ below the right costal margin and her haemoglobin concentration had fallen to $5.6 \mathrm{~g} / \mathrm{dl}$, with a reticulocyte count of $15^{\prime \prime}$, Six hours later her liver extended $12 \mathrm{~cm}$ below the right costal margin. Liver function tests showed bilirubin concentration $110 \mu \mathrm{mol} / 1$ $(6.4 \mathrm{mg} / 100 \mathrm{ml})$, aspartate transaminase activity $90 \mathrm{IU} / \mathrm{l}$, and alkaline phosphatase activity $275 \mathrm{IU} / 1$. Three units of blood were transfused, and over the next three days the size and function of her liver returned to normal.

A year later she was admitted with bone pain. On this occasion her liver was palpable $5 \mathrm{~cm}$ below the right costal margin. The haemoglobin concentration was $5 \cdot 7 \mathrm{~g} / \mathrm{dl}$ and reticulocyte count $5^{\prime \prime}{ }^{\prime \prime}$, and results of liver function tests were unremarkable. The following day the liver was enlarged $7 \mathrm{~cm}$ below the right costal margin, her haemoglobin concentration was $5.0 \mathrm{~g} / \mathrm{dl}$, and the reticulocyte count was $8^{\circ} \%$. Four units of blood were transfused, and over the next four days her liver returned to normal size.

Five days later she was readmitted with a two day history of passing dark urine and a one day history of pain in the right iliac fossa. She was jaundiced and tender in the right iliac fossa and epigastrium. Her liver was palpable $5 \mathrm{~cm}$ below the right costal margin. On admission the haemoglobin concentration was $6.1 \mathrm{~g} / \mathrm{dl}$. Her liver enlarged gradually until it was palpable $9 \mathrm{~cm}$ below the right costal margin. There were no signs of cardiac failure. Liver function tests showed bilirubin concentration $185 \mu \mathrm{mol} / 1(10.8 \mathrm{mg} / 100 \mathrm{ml})$, aspartate transaminase activity $234 \mathrm{IU} / 1$, and alkaline phosphatase activity $650 \mathrm{IU} / 1$, and a liver scintigram showed generalised hepatic enlargement. Ultrasonography showed a normally contracting and filling gall bladder. Over the subsequent few days her haemoglobin concentration dropped to $4.2 \mathrm{~g} / \mathrm{dl}$ with a reticulocyte count of $27^{\circ}$, and the liver remained massively 
enlarged. Because of cross matching problems she could not be given blood transfusions. Over the next seven days her liver returned to $3 \mathrm{~cm}$, her haemoglobin concentration rose spontaneously to $7.5 \mathrm{~g} / \mathrm{dl}$, and her liver function improved.

\section{CASE 2}

An 18 year old woman with homozygous sickle cell anaemia was admitted with a painful crisis, which had been preceded by an upper respiratory tract infection. She had suffered repeated painful crises

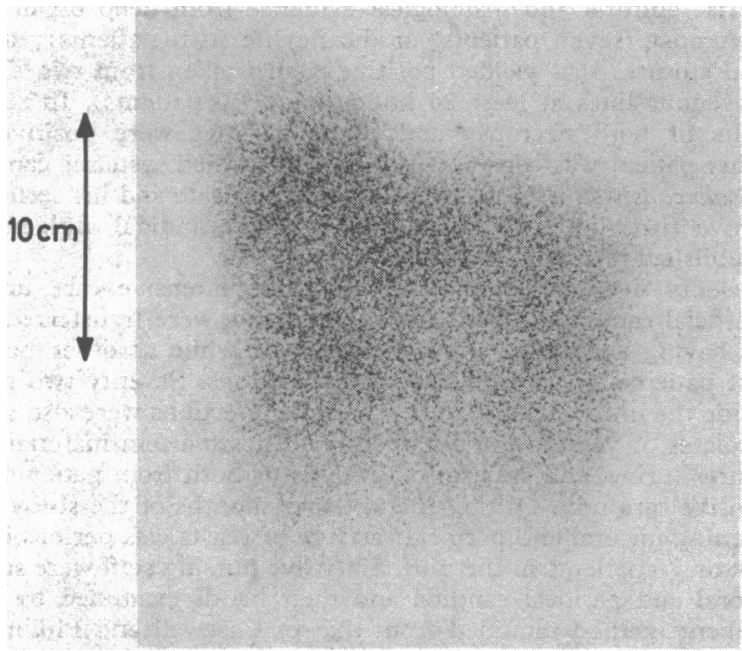

FIG 1-Liver scintigram, anterior view (technetium-99m tin colloid), showing diffusely enlarged liver.

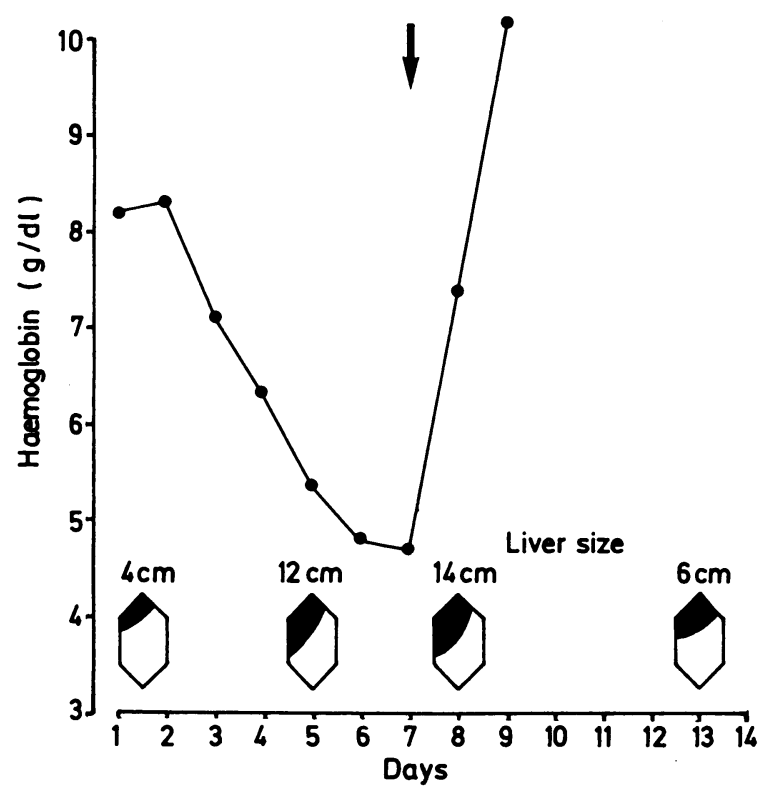

FIG 2-Fall in haemoglobin concentration $(\mathrm{g} / \mathrm{dl})$ associated with rapid enlargement of liver (measured in $\mathrm{cm}$ below right costal margin). Patient received two units of blood on day 7 (arrowed).

and had had two episodes of the acute chest syndrome. She was mildly jaundiced and feverish. Respiratory and cardiovascular examinations gave normal results. Her liver was just palpable $4 \mathrm{~cm}$ below the right costal margin. Initial haematological investigations showed haemoglobin concentration $8.3 \mathrm{~g} / \mathrm{dl}$, white cell count $15.3 \times 10^{\%} / 1$, and reticulocyte count $8 \%$. Liver function tests showed bilirubin concentration $30 \mu \mathrm{mol} / 1(1.8 \mathrm{mg} / 100 \mathrm{ml})$, aspartate transaminase activity $45 \mathrm{IU} / 1$, and alkaline phosphatase activity $570 \mathrm{IU} / 1$. She was treated with intravenous fluids, analgesics, and antibiotics. Over the next three days her liver became tender and enlarged to $14 \mathrm{~cm}$ below the right costal margin (fig 1), and her haemoglobin concentration fell to $4.8 \mathrm{~g} / \mathrm{dl}$ with a reticulocyte count of $19 \%$ (fig 2 ). There was a modest change in the results of liver function tests: bilirubin concentration $20 \mu \mathrm{mol} / 1(1 \cdot 2$ $\mathrm{mg} / 100 \mathrm{ml})$, aspartate transaminase activity $120 \mathrm{IU} / \mathrm{l}$, and alkaline phosphatase activity $810 \mathrm{IU} / 1$. Two units of packed cells were transfused. The liver rapidly regressed to $6 \mathrm{~cm}$. Two weeks later she was readmitted with a further painful crisis and her liver was enlarged $7 \mathrm{~cm}$ below the right costal margin.

\section{Discussion}

Several episodes of severe hepatic enlargement associated with a dramatic fall in haemoglobin concentration occurred in these two patients with sickle cell anaemia. Liver function tests did not yield greatly abnormal results, there was no evidence of gall bladder disease or cardiac failure, and the liver returned to normal size over a few days. The appreciable fall in haemoglobin concentration was associated with appropriate reticulocytosis.

The fall in haemoglobin concentration associated with a rapid increase in the size of the organ observed in these patients is similar to that seen in the splenic sequestration crisis of early life, in which there is good postmortem evidence of massive sequestration of sickled cells in the spleen. ${ }^{3}$ Recent studies suggest that the sequestration of sickled erythrocytes in the pulmonary circulation, which seems to underlie the sickle lung syndrome, is also preceded by an acute drop in the haemoglobin concentration and by reticulocytosis. ${ }^{3}$ It is likely, therefore, that the acute enlargement of the liver observed in these patients was due to the sequestration of large numbers of sickled erythrocytes in the hepatic circulation. It is not clear whether all sequestered sickle cells are destroyed or whether some of them return to the circulation; the remarkably rapid rise in haemoglobin concentration from 4.2 to $7.5 \mathrm{~g} / \mathrm{dl}$ over five days without transfusion in our first patient's second episode suggests that some sequestered erythrocytes may be redistributed.

The role of the liver in sickle cell disease is well recognised. In a detailed review of 50 patients with sickle cell anaemia 33 were noted to have enlarged livers at some time during their illness. ${ }^{5}$ The reviewers also noted that the liver may become enlarged during episodes of crisis. Postmortem studies in 21 cases suggested that hepatic dysfunction was the result of severe impairment of hepatic blood flow from the combined effects of anaemia, sickling of red cells in hepatic sinusoids, and obstruction caused by Kupffer's cells engorged with red blood cells. This series contained four cases of unequivocal cirrhosis, a complication that has been noted by others. ${ }^{7}$ Acute localised hepatic damage due to sequestration of sickled cells is therefore fairly common, and chronic structural damage may also occur.

Acute hepatic enlargement in patients with sickle cell anaemia has not been emphasised in recent accounts of the disorder, and the prevalence of this complication is not known. In the acutely distressed patient with bone pain it may be easy to miss hepatic enlargement, particularly if it was not present at the first examination. The observations in these patients suggest that regular and scrupulous examination of hepatic size, particularly when there is a precipitous fall in haemoglobin concentration, should form part of the management of patients with sickle cell crisis.

We thank Dr B J Shepstone for his help in performing and interpreting the liver scintigram, and Miss Elizabeth Gunson for typing the manuscript.

\section{References}

1 Serieant GR, Topley JM, Mason K, et al. Outbreak of aplastic crises in sickle cell anaemia associated with parvovirus-like agent. Lancet 1981;ij:595-7. deaths in Jamaican children with sickle cell disease. Br Med F 1978;i:1515-6. Davies SC, Luie PJ, Win AA, Riordan JF, Brozovic M. Acute chest syndrome in sickle cell disease. Lancet $1984 ; \mathrm{i}: 36-8$.

4 Henderson AB. Sickle cell anaemia. Clinical study of 54 cases. Am $\mathcal{F}$ Med 1950;8: 757

5 Green TW, Conley CL, Berthrong M. The liver in sickle cell anemia. Bulletin of the Johns Hopkins Hospital 1953;92:99-127.

7 Bauer WT, Moore GW, Hutchins GM. The liver in sickle cell disease. Am 7 Med $1980 ; 69: 833-7$.

(Accepted 8 fanuary 1985) 